\title{
Translating Legal Terms in Context
}

\author{
Antoinette Sedillo López
}

\begin{abstract}
This article reviews a number of Spanish/English legal dictionaries, evaluating the relative merits and features of each. Translating legal terms requires an understanding of both the legal context in which the term is used and the legal context in which the translation is intended. Thus, this review of legal dictionaries concentrates on evaluating the authors'/editors' understanding of how the terms are used in the two legal cultures, as well as in two different languages. [Article copies available for a fee from The Haworth Document Delivery Service: 1-800-342-9678. E-mail address: getinfo@haworthpressinc.com <Website: http:// www.haworthpressinc.com>]
\end{abstract}

KEYWORDS. Dictionaries, Legal Dictionaries, Bilingual Dictionaries, Spanish/English Dictionaries, Spanish Legal Terms.

Translating and interpreting skills require a bilingual facility that is beyond the reach of most individuals. This is especially true with respect to translating legal terminology. Translating legal terms requires an understanding of both the legal context in which the term is used and the legal context in which the translation is intended. Bilingual lawyers, business men and women, interpreters and law professors who travel, study and do business in English speaking and Spanish speaking countries have found that attempting to translate word for word can result in serious miscommunication. The legal system in English speaking countries is based on the common law tradition while Spanish speaking countries rely on the civil law tradition. ${ }^{1}$ False

Antoinette Sedillo López is Professor of Law, University of New Mexico, 1117 Stanford NE, Albuquerque, NM 87131. She received her JD from UCLA in 1982 and her Bachelor's in 1979 from the University of New Mexico.

Legal Reference Services Quarterly, Vol. 17(4) 1999

(c) 1999 by The Haworth Press, Inc. All rights reserved. 
cognates and different legal concepts can induce a bilingual person to use words that have a completely different meaning to the listener than that intended by the speaker.

For example, early in my academic career, on a professor exchange program in Mexico, ${ }^{2}$ I made a few translation errors. In speaking about the topic of Reproductive Technology and the Law ${ }^{3}$ at the Universidad de Guanajuato, I spoke of "jurisprudencia" intending the meaning "legal philosophy." I was met with blank stares. My topic did not seem relevant to any case the Mexican Supreme Court had resolved in the same manner five times. "Jurisprudencia" in Mexico refers to the event of the Mexican Supreme Court deciding a case the same way five times and thus creating binding precedent. ${ }^{4}$ I used the term "madre subrogada" to refer to "surrogate mother." My Mexican colleagues looked confused. "Madre subrogada" meant literally "substitute mother" but they did not understand the context the first time I used the term. Needless to say, I learned a great deal from the experience. I have heard similar stories in talking to bilingual lawyers, business people, interpreters and academics. Thus, legal professionals involved in cross-border work need a first-rate Spanish/English legal dictionary. In reviewing the following dictionaries, my primary criterion is whether the dictionary helps the user understand the legal context of the translation. 5

Professors Ramos Bossini and Gleeson have recently published a vital addition to legal lexicography, in their Diccionario de Términos Juridicos. ${ }^{6}$ The most important aspect of this legal dictionary is that the definitions of legal terms are not simply translations. Each term is explained in its proper legal context. For example, "intellectual property" is not translated as simply "propriedad intelectual." Instead, the term is explained in Spanish: "El término hace referencia a aquellos trabajos creativos, originales, que pueden ser protegidos por la ley. La norma jurídica en el ámbito nacional e internacional, tiene establecida una protección para las invenciones científicas, las creaciones artísticas y los diseños comericales o industriales, por lo que los derechos del author, las marcas registradas y las patentes evitan, con la protección legal, que sean copiados, difundidos, vendidos or representados sin el oportuno permiso..." The entry then lists types of intellectual property and the international treaties regarding rights of authors, and the difficulty of controlling intellectual property in these days with photocopiers, scanners and the Internet. The term "buenos oficios" is 
translated as "Mediation, good offices. In public and international law, the offer by a third party to mediate between the belligerents; action of a person who accomplishes something for another." "Censo enfitéutico" is translated as "Emphyteusis" and then thankfully explained as "perpetual lease; a grant of use of land forever on condition that an annual rent (canon) be paid to the grantor and his or her successors (who reserve legal ownership)." "Battered wife" is "Proyecto de nueva normativa en UK tendente a proteger a la exposa que sufre violencia física por parte de su marido." The entry goes on to explain the domestic violence legislation in the United Kingdom. My only quarrel with this definition is that similar legislation also exists in the United States and Canada. ${ }^{7}$ The book is comprehensive. It attempts to include legal terms used in all English speaking countries and in all Spanish speaking countries.

Luis Miguel Diaz and Ben Lenhart have published a useful tool for Mexico /United States work involving business and the North American Free Trade Agreement (NAFTA). ${ }^{8}$ Their dictionary is intended as a quick reference source for those working in international law and in commerce involving U.S. and Mexico. The dictionary focuses on Mexican Spanish and U.S. English. The 1997 edition contains appropriate definitions of terms under NAFTA and the labor and environmental side agreements. For example, "the North American Agreement on Labor Cooperation (NAALC)" is translated as "Acuerdo de Cooperacion Laboral de America del Norte (ACLAN)." "Condiciones minimas de trabajo" is defined as "the establishment of minimum employment standards such as minimum wages and overtime pay, for a wage earner, including those not covered by collective agreements" and the appropriate provision of NAALC is cited. However, in the preface, the authors state that they have determined that some Mexican terms should not be included in Spanish to English and vice versa to explain why they did not cross reference their work. I do not understand that decision. For example, they included a Spanish entry for "abuso infantil (maltrato)" defined as "child abuse," but there is no English entry for "child abuse." Further, the Spanish definition for abuse "abuso" is listed simply as "abuso" but "abuso" also commonly means embezzlement as in "abuso de confianza." Then there is no entry for "spousal abuse" or "domestic violence." Someone could conclude that "abuso de la esposa" or "violencia domestica" would be appropriate terms. However, the most common 
term for spousal abuse is "maltrato de la esposa" or "violencia contra la mujer." 9

Of assistance to those in need of Spanish terminology in the banking industry, Hermalinda Guardiola Dunagan has published the English/Spanish \& Spanish /English Banking and Legal Dictionary. ${ }^{10}$ This comprehensive dictionary contains many entries of special interest to those in need of bilingual banking services. It contains multiple entries for terms that have multiple meaning. For example, "check" is defined as "cheque, talón, comprobación, prueba, compulsa, confronta, cotejo, comporbar, verificar, revisar, compulsar, cotejar, confrontar. These multiple entries reveal the variety of meanings of "check" as a noun meaning a banking document or as evidence or proof of a monetary transaction. As the entry demonstrates "check" also means to review, to verify, to audit, to require verification. While the dictionary does not regularly set out an explanation of the context for the term translated, its utility lies in the scope of its coverage and its translation of specialized banking terminology.

Another resource is the Diccionario de Termininos Legales, Espanol-Ingles e Ingles-Espanol by Louis Robb. ${ }^{11}$ It has been available for many years and has proved useful. The most recent edition contains fairly broad coverage and identifies when a term or definition is a regionalism used only in one or two countries. However, it tends to simply translate the term and very rarely explains the legal context for the term. For example, "jurisprudencia" is defined as "jurisprudence, law, body of laws; court decisions." The Mexican meaning is not included. This failure to explain the legal terms in context limits its utility.

Butterworth's two volume Spanish/ English Legal Dictionary ${ }^{12}$ is an excellent resource as it also explains legal concepts when there is no equivalent translation that is the same legal concept. It is comprehensive in scope and contains a large volume of entries. The entries contain Latin terms that are used in the civil law system and Latin terms used in the common law system. For example, "jus commun" is translated as "derecho comun" but the entry goes on to state that "no equivale al concepto de "common law"." Unfortunately the authors did not include common American legal concepts such as "Fourth Amendment" when explaining search and seizure, as an example. While it is an excellent translation tool, as a two-volume set, it is rather bulky for travel. 
An excellent scholarly work is Dahl's Law Dictionary/Diccionario Juridico. ${ }^{13}$ The author identifies two types of definitions: (1) authoritative definitions that refer directly to the relevant parts of code or statutes, judicial decisions and other legal writing: and (2) definitions based on synonyms. The references to the codes offer a helpful explanation of context. His new edition contains references to the Spanish Civil Code, the Civil Code of Louisiana and the Standard Penal Code of Latin America, decisions from the Puerto Rico Supreme Court and to a lesser extent the Mexcian Civil Code and Labor Code and the codes of some Latin American countries. The references to the Louisiana Civil code is a bit of a mystery since Louisiana's civil code is based on the French as well as the Spanish civil code tradition, and in any event, is not normally authoritative with respect to Latin American or Spanish legal regimes. At the end of the dictionary is a Table of Key Words. The table of the subject matter of the entries helps a user to review the materials in a subject area even if the user is unsure of the exact word sought.

I was disappointed that the definition for "amparo" does not authoritatively quote the constitutional provisions and codes that create the procedure of amparo. Dahl's entry gives a bit of the history of "amparo" pointing to the 1772 Fueros de Aragon as the possible origination. While it mentions the Mexican Constitution, it also states that there is U.S. influence on the procedure. Mexican law teachers have emphatically informed me that amparo is unique and not influenced by U.S. forms of action. While I agree that amparo is unique, I cannot comment on the influences on the process and it surprises me that Dahl does so with such confidence. ${ }^{14}$ The entry concludes with "protection against the abuse of public authority. Mandamus." This is in contrast to the encyclopedic treatment of other entries that refer.to an authoritative code or constitutional provision that provides for and explains the legal concept. Nonetheless, the work's strength is the scholarly, thorough and contextual treatment of the terms the author chooses to elaborate upon. The third edition is very impressive.

Wiley's English Spanish/ Spanish English Legal Dictionary ${ }^{15}$ simply presents word equivalents. With 30,000 entries for each language it is comprehensive, however, it is disappointing in its failure to explain legal terms. Some equivalents fail to convey the correct meaning. For example "amparo" is translated as "protection, support, pardon, exemption, defense." The entry fails to describe its legal 
meaning as a proceeding used to protect constitutional rights in Mexico and other Latin American countries.

In 1992 Julio Romanach Jr. published a paperback edition of a legal dictionary that is useful and portable. ${ }^{16}$ Important terms are sometimes explained in legal context. For example, "Full Faith and Credit Clause" is explained as "Cláusula de la constitución de los E.E.U.U. exigiendo el reconocimiento de los actos publicos y decisiones judiciales de cada Estado por los demás estados de la Union." However, some terms that require explanation are not explained and on occasion, secondary meanings that are very important are left out. For example, "aborto" is simply translated as "abortion." However, "aborto" also means "miscarriage" or an unintentional termination of pregnancy. George Vanson and Marilyn Taylor published an excellent little dictionary in $1985 .{ }^{17}$ The dictionary was developed as a companion volume for the text Skills for Bilingual Legal Personnel: Translating, Interpreting and Cultural Fluency. Both volumes are used in advanced language courses emphasizing translating and interpreting. Because the context is so important to an adequate translation, a Spanish sentence follows each entry using the term in its proper context and an English translation. This is very effective in demonstrating the correct context for the term. Unfortunately the words covered are primarily about the American legal system. Spanish forms of action and legal terminology are simply very sparse or translated to an American counterpart rather than explained in the civil law context. For example "patria potestad" is translated as "parental authority." The specific obligations imposed by the civil law doctrine are not described or explained. The amparo proceeding is not described. Thus, it is not comprehensive enough for use in international transactions.

Vega's English/ Spanish Dictionary of Everyday Criminal and Legal Terms ${ }^{18}$ is primarily for use in the United States to explain American criminal system legal terms to a Spanish speaker. It is an excellent tool for interpreters to help explain the functions of our criminal system to a Spanish speaker. It contains a pronunciation guide, a summary of important dates in Latin American nations' history, a Spanish language version of the "Miranda warning," Spanish terms for the human body, some basic medical terms and useful everyday information. Terms, especially important stages of the criminal process, are explained.

Another bilingual dictionary useful for helping translate for Spanish 
speaking individuals in need of understanding the United States Criminal Justice system was written by Virginia Benmaman, Norma C. Connolly and Scott Robert Loos. ${ }^{19}$ The authors, a professor of Spanish, a lawyer who is accredited as a translator, and a court interpreter have done an impressive job of identifying terms of high frequency usage in the criminal justice system. The definitions are written in non-technical language so as to be understood by users who are not necessarily lawyers. The book is the result of a research project funded by the State Justice Institute. The project involved identifying high frequency work usage in the states with a significant number of monolingual Spanish speakers and consulting with a multidisciplinary team of experts, such as attorneys, judges, court administrators, linguists, professors and practicing interpreters. A panel of bilingual judges served as an Advisory Board and were offered the opportunity to review the material before publication. The result is a comprehensive and highly usable tool for translating for monolingual speakers who find themselves in need of understanding the United States criminal justice system. The book contains criminal procedure flowcharts, penal offense charts, definitions and an index for help in finding English terms when the Spanish term is known. However, the index is not intended for use in translating Spanish terms to English. The English term is presented in a column side by side the Spanish term. There are many explanatory notes and usage tips. The book admirably serves its purpose.

While legal dictionaries are crucial in assisting bilingual lawyers, businesspersons, interpreters and academics, they do not replace the need to learn and understand the legal framework and the economic and business contexts. Understanding the differences in the systems is vital to cross-border work. As anyone who speaks a second language (or who writes poetry) knows: words are only as useful as the sense in which they are understood. A failure to communicate by poor word choice or failing to understand the appropriate context can be costly indeed.

\section{NOTES}

1. See generally JOHN HENRY MERRYMAN, THE CIVIL LAW TRADITION (2d ed. 1985).

2. In 1987 the University of New Mexico and the Universidad de Guanajuato began a professor exchange program, originally funded by a USAID grant obtained by Professor Charles DuMars. The program spawned a Summer Institute for Com- 
parative and International Studies located at the Universidad de Guanajuato and cosponsored by a consortium consisting of the University of New Mexico, Texas Tech School of Law, Southwestern Law School and the Universidad de Guanajuato Facultad de Derecho. Professor William T. MacPherson started the Institute in 1990. The author has taught in the Institute regularly and served as director in 1994 and co-director in 1996.

3. Antoinette Sedillo López, La Privacidad y la Regulacion de las Nuevas Tecnologias de La Reproducion: Un Plantamiento para tomar Deciciones, 37 INVESTIGACIONES JURIDICOS 442 (1990) Antoinette Sedillo López, Two Legal Constructs of Motherhood: "Protective" Legislation in Mexico and the United States, 1 USC REV. L. \& WOMEN STUDIES 239 (1992) Antoinette Sedillo López, Surrogates, Test Tube Babies and Frozen Embryos: Searching for Solutions, 20 N.M.L. Rev. 701 (1990); Antoinette Sedillo López, Privacy and the Regulation of the New Reproductive Technologies, 22 FAMILY LAW Q. 173 (Summer 1988).

4. This normally occurs in instances where the Mexican codes are not directly on point.

5. This review makes general comments about the legal dictionaries reviewed and uses examples as illustrations. It is not a word for word comparison of the dictionaries.

6. FRANCISCO RAMOS BOSSINI \& MARY GLEESON, DICCIONARIO DE TERMINOS JURIDICOS: INGLES-ESPANOL; ESPANOL-INGLES (MacGraw Hill 1998).

7. I understand that Professor Bossini is correcting this in the second edition.

8. LUIS MIGUEL DIAZ \& BEN LENHART, DICCIONARIO DE TÉRMINOS JURIDICOS' (3rd ed. 1997) Themis, Mexico.

9. These terms are very important for the practice of International Family Law such as litigation under the Hague Convention on the Civil Aspects of Child Abduction (1980) and the Hague Convention on Jurisdiction, Applicable Law, Recognition, Enforcement and Co-operation and Respect of Parental Responsibility and Measures for the Protection of Children and Decisions on Matters Pertaining to the Agenda of the Conference (1996).

10. HERMALINDA GUARDIOLA DUNAGAN, ENGLISH/SPANISH \& SPANISH/ENGLISH BANKING AND LEGAL DICTIONARY (1995) New Mexico Bankers Association

11. LOUIS A. ROBB, DICCIONARIO DE TÉRMINOS LEGALES: ESPANOLINGLES E INGLES-ESPANOL (1991) Editorial Limusa.

12. GUILLERMO CABANELLAS DE LAS CUEVAS \& ELEANOR C. HOAGUE, BUTTERWORTH'S SPANISH/ENGLISH LEGAL DICTIONARY (1991) Butterworth Legal Publishers.

13. HENRY S. DAHL, DAHL'S LAW DICTIONARY/DICCIONARIO JURIDICO (3d ed. 1999). William S. Hein \& Co. Inc.

14. Bruce Zagaris, The Amparo Process in Mexico, 6 U. S.-Mex. L. J. 61 (1998). 15. STEVEN M. KAPLAN, WILEY'S ENGLISH-SPANISH, SPANISH ENGLISH LEGAL DICTIONARY (2d ed. 1997) Wiley Law Publications, John Wiley \& Sons, Inc. 
16. JULIO ROMANACH, JR., DICTIONARY OF LEGAL TERMS: SPANISHENGLISH/ENGLISH-SPANISH (1992) Lawrence Publishing company.

17. GEORGE VANSON \& MARILYN TAYLER: SPANISH-ENGLISH LEGAL TERMINOLOGY (1985) SCOTT FOREMAN AND COMPANY.

18. CARLOS B. VEGA (WITH THE ASSISTANCE OF ANTHONY M. DEFINO), VEGA'S ENGLISH SPANISH DICTIONARY OF EVERYDAY CRIMINAL \& LEGAL TERMS (1982) V. \& A. Communications Inc.

19. VIRGINIA BENMAMAN, NORMA C. CONNOLLY \& SCOTT ROBERT LOOS, BILINGUAL DICTIONARY OF CRIMINAL JUSTICE TERMS (ENGLISH/SPANISH) (1991) Gould Publications.

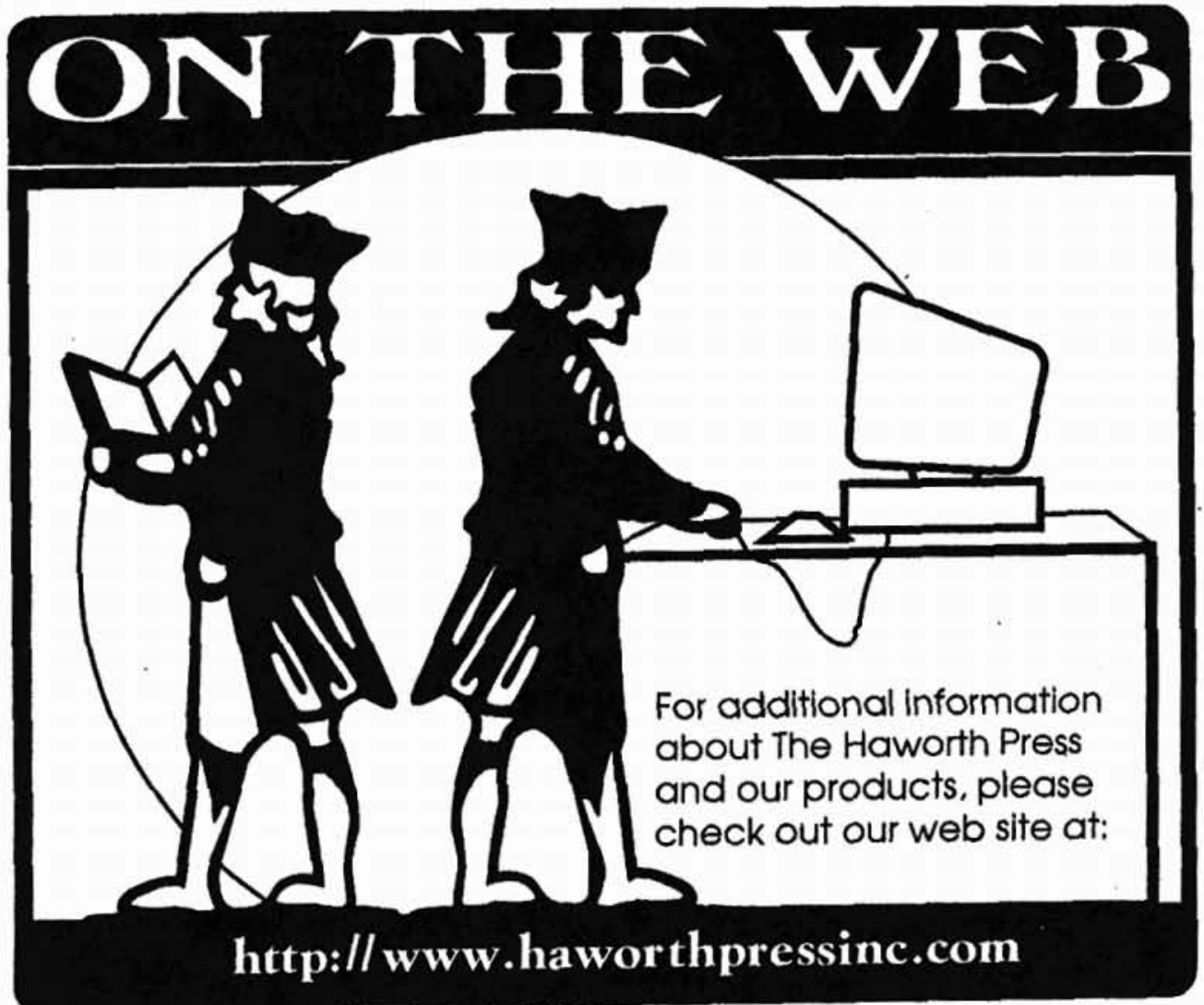

